\title{
STUDYING THE INFLUENCE OF SOIL SALTING ON THE GROWTH, DEVELOPMENT AND PRODUCTIVITY OF TOMATO IN THE CONDITIONS OF THE REPUBLIC OF KARAKALPAKISTAN
}

\author{
M.Yu. Ibragimov \\ Nukus branch of Tashkent State Agrarian \\ University, \\ Nukus, Karakalpakstan, \\ Uzbekistan
}

\author{
A.A. Nurkhojaeva \\ Nukus branch of Tashkent State Agrarian \\ University, \\ Nukus, Karakalpakstan, \\ Uzbekistan
}

\author{
M.S.Jadigerova \\ Nukus branch of Tashkent State Agrarian University, \\ Nukus, Karakalpakstan, \\ Uzbekistan
}

Article DOI: $\underline{\text { https://doi.org/10.36713/epra2496 }}$

\begin{abstract}
The article discusses the issues of soil salinization and their influence on the growth, development and productivity of tomato. As a result of the study, soil salinization has an effect on seed germination. When salinization occurs, there is a low percentage of germination, emergence and passage of the phase of plant development are delayed, the fruits ripen on 10-14 days later compared to control plants. There is a decrease in the number of fruits and plant productivity. It is recommended to use the most salt tolerant and productive in production zoned varieties: Volgogradsky 5/95, Dark Red 2027, Andijan, October and from hybrid varieties Inkos (Inkos) $F_{1}, A K-T O R F_{1}$, Shedi-Lady (Shady Lady) $F_{1}$.

KEYWORDS: Varieties, hybrids, plants, phenology, growth, development, seed germination, emergence of seedlings, budding, flowering, fruit ripening, fruit, fruit formation, productivity, yield, salinity of the soil, vegetation, vegetative organs.
\end{abstract}

\section{INTRODUCTION}

The main vegetable culture of Uzbekistan is tomato. Tomato fruits are valued for their high taste and dietary qualities, serve as one of the most important sources of biologically active substances and antioxidants that protect the human body from oxidative stress and inhibit aging processes. Due to the increasing demand of the domestic market and export opportunities for fresh fruits and tomato products, there is a need to increase tomato production mainly due to increased yields.

The Republic of Karakalpakistan is located on the northern lowland part of Central Asia and is administratively part of the Republic of Uzbekistan.
The region is characterized by a sharply continental climate: intense insolation, increased air dryness, low rainfall. The main irrigated land fund of the region is located on meadow, meadow-takyr, meadow- desert, meadow-alluvial soils. The total irrigated land area in the Republic is 510.40 thousand hectare, of which $360.54(71 \%)$ thousand hectare are saline to varying degrees. Because bioecology and methods of tomato cultivation are not well understood, scientific research on the selection of varieties and improvement of tomato cultivation technology is an urgent problem that is important for the development of vegetable production in the country. 
The purpose and objectives of the study. The purpose of this study is to select more salt tolerant $F_{1}$ varieties and hybrids and to study the effect of soil salinization on the growth, development and yield of tomato in the open ground in the region. To achieve the intentional goal, the following research tasks are formed:

- Definitions of the experimental site by the degree of salinity of the soil

- Studies of the salt tolerance of tomato varieties and hybrids.

- Studies of the effect of soil salinization on seed similarity

- Studies of the effect of soil salinization on plant growth, development and productivity.

\section{METHODS OF CONDUCTING THE EXPERIMENT}

Research methods. When performing the work, the following methods and guidelines were used: "Methods of field experience in vegetable growing and melon growing" [12,] "Methods of agrochemical, agrophysical and microbiological research in irrigated cotton areas" Union of NIHI [13], B.R. Armor "Methodology of the field experiment", Moscow "Kolos" [4], B.Zh. Azimov, B.B. Azimov "Sabzavotchilik, polischilik va potato chilikda tazhribalar казtkakish methodikasi" [1], B.Zh. Azimov, B. B. Azimov "Tazhribanatizhalining statistics hid" [2].

Place of research. The place of research and the experimental part of the work was carried out at the departments "Fruit growing, vegetable growing and melon growing" of the Nukus branch of the Tashkent State Agrarian University and in the "D.F.K. Kattagar plot" (Nukus district). The soil of the experimental plot is meadow-alluvial, old-irrigated, medium loamy, slightly saline (chloride-sulphate type) in mechanical composition. Groundwater occurs during the growing season at a depth of 1.5$2.2 \mathrm{~m}$ from the soil surface. Before laying the experiment After irrigation, the arable horizon contained: humus $0.7-1.25 \%$, gross nitrogen 0.068 $0,079 \%$, gross phosphorus $0.114-0.155 \%$, nitrate nitrogen $15.7-17.5 \mathrm{mg} / \mathrm{kg}$, mobile phosphorus 14.3 $8.5 \mathrm{mg} / \mathrm{kg}$ and exchange potassium 242.5-285.0 $\mathrm{mg} / \mathrm{kg}$ of soil weight.

Research on the topic being developed was carried out on the following field experiments:

1. Study of the effect of soil salinization on the growth, development and productivity of tomato on open ground; (cultivar Volgogradsky 5/95)

2. Selection of highly salt tolerant and highly productive varieties and hybrids of tomato on the open ground.

\section{Experience Options}

1. A plot of non-saline soil (the salt content in the soil is chloro-ion $0,010 \%$ and a solid residue of $0,239 \%$ - control).
2. A plot of slightly saline soil (the salt content in the soil is chloro-ion $0,017 \%$ - a solid residue of $0,342 \%$ ).

3. A plot of medium-saline soil (the salt content in the soil is chloro-ion $0,030 \%$, the solid residue is $0,536 \%$ ).

4. A plot of strong saline soil (the salt content in the soil is chloro-ion $0,113 \%$, density $1,033 \%)$.

The area of the registration plot is $5 \mathrm{~m}^{2}$. The experiment was repeated four times. Sowing was carried out on April 25, 2018-2019 year, the sowing scheme was $90 \times 25 \mathrm{sm}$. Starting from the phenophase of the appearance of the first true leaves, the plants were fed with mineral fertilizers. Systematically watering, loosening and combating pests.

\section{RESEARCH RESULTS AND THEIRDISCUSSION}

The process of soil salinization is a serious environmental factor affecting the development and productivity of almost all economically important plants; therefore, it has been the subject of study by many researchers $[10,11,8]$. Soil salinization is intensive in areas where upstream soil currents groundwater consumed by evaporation and transpiration prevail over the level of downstream currents, provided that the mineralized groundwater levels are close and their outflow is difficult [5].

V.A. Kovda (1947) identified four types (provinces) of salt accumulation in soils: chloride, sulfate-chloride, chloride-sulfate and sulfate-soda [10]. Most of the territory of Central Asia, including the lower reaches of the Amu Darya River, to the provinces chloride-sulfate, sulfate, sulfate-chloride.

P.A. Genkel (1954) distinguished two main groups of plants with respect to soil salinization: halophytes (plants of saline habitats) and glycophytes (plants of fresh habitats) [3]. N.V. Orlovsky (1951) proposed his classification of crops by signs of salt tolerance: especially, medium and unstable [14]. According to this classification, sugar beet, fodder and table beet are particularly resistant; winter rye, spring wheat, double row barley, oats, tomatoes, cabbage, turnip are classified as medium resistant, radish, turnip, tour with carrots, potatoes, to unstable - sunflower, lettuce, spinach, chicory, beans, green beans, peas, onions, garlic, cucumbers, vetch, radish.

Studies of the effects of soil salinization on vegetables and melons are also devoted to studies [5, $7,16,15,6$,$] .$

E.M. Kovalskaya (1958) established that chloride salinization is most harmful to tomatoes, especially when it suddenly acts and does not adapt to it [9]. Tomatoes have the lowest salt tolerance at an early age and during flowering; at other periods, more stable.

Observations showed that varying degrees of salinization of the soil affects the field germination of tomato seeds (1 table). 
As can be seen from Table 1, seed germination in saline soil is $57-69 \%$ (in the control plant $87 \%$ ), seedlings are absent in highly saline soil. The concentration of salts in the soil negatively affects the growth of young plants.
It was found that various degrees of salinization of the soil affect the passage of the phenological phase of plant development (2-table).

Table 1

The effect of soil salinization on field germination of tomato seeds (cultivar Volgogradsky 5/95, 2018-2019 year)

\begin{tabular}{|c|c|c|c|c|c|}
\hline \multirow{2}{*}{ Soil salinity } & \multicolumn{2}{|c|}{$\begin{array}{l}\text { The salt content in the } \\
\text { soil, } \%\end{array}$} & \multirow{2}{*}{$\begin{array}{c}\text { Sowing } \\
\text { date }\end{array}$} & \multirow{2}{*}{$\begin{array}{c}\text { The beginning } \\
\text { of the } \\
\text { emergence of } \\
\text { seedlings, days }\end{array}$} & \multirow{2}{*}{ Germination, $\%$} \\
\hline & chlorine & $\begin{array}{l}\text { Residue } \\
\text { density }\end{array}$ & & & \\
\hline $\begin{array}{l}\text { Not saline } \\
\text { (control) }\end{array}$ & 0.010 & 0.239 & 25.04 & 4 & 87 \\
\hline Weak & 0.017 & 0.342 & 24.04 & 6 & 69 \\
\hline Average & 0.030 & 0.536 & 25.04 & 8 & 57 \\
\hline Strong & 0.113 & 1.033 & 29.04 & \multicolumn{2}{|c|}{ No seedlings } \\
\hline
\end{tabular}

Table 2

The effect of soil salinization on the passage of the phenological phases of tomato development (number of days from germination, 2018-2019 year)

\begin{tabular}{|c|c|c|c|c|c|c|c|}
\hline Soil salinity & \multicolumn{2}{|c|}{$\begin{array}{c}\text { The salt content in } \\
\text { soils, \% }\end{array}$} & Seedlings & $\begin{array}{c}\text { Appearance of } \\
\mathbf{1 - 2} \text { true leaves }\end{array}$ & $\begin{array}{c}\text { Butanizati } \\
\text { on }\end{array}$ & $\begin{array}{c}\text { Flowerin } \\
\text { g }\end{array}$ & $\begin{array}{c}\text { Ripening } \\
\text { fruit }\end{array}$ \\
\hline $\begin{array}{c}\text { Not saline } \\
\text { (control) }\end{array}$ & 0.010 & 0.264 & 29.04 & 5 & 34 & 50 & 80 \\
\hline Weak & 0.017 & 0.342 & 1.05 & 6 & 33 & 53 & 90 \\
\hline Average & 0.030 & 0.536 & 3.05 & 8 & 36 & 57 & 94 \\
\hline
\end{tabular}

As follows from the data in Table 2, under saline soil, seedlings appear 1-3 days later, delay flowering for 3-8 days, the ripening phase of the fruits is delayed 10-14 days compared to control plants.

It was found that salinization of the soil affects the formation of fruits and tomato productivity (table-3).
As a result of the study, it was found that a low degree of salinity contributes to an increase in the number of ripened fruits and their mass, and therefore the total yield of plants increases. With saline soil, the yield was 30.1-47.9 $\mathrm{t} /$ hectare, in control plants it was $56.2 \mathrm{t} / \mathrm{ha}$. This means that when cultivating tomato in the region, it is necessary to sow on non-saline and slightly saline soils.

Table 3

The effect of soil clogging on fruit formation and tomato yield

\begin{tabular}{|c|c|c|c|c|}
\hline Soil salinity & $\begin{array}{c}\text { The number of ripened } \\
\text { fruits, pcs }\end{array}$ & $\begin{array}{c}\text { The average weight of } \\
\text { the fruit, } \mathbf{g}\end{array}$ & $\begin{array}{c}\text { Plant } \\
\text { productivity, g }\end{array}$ & $\begin{array}{c}\text { Productivity, } \\
\text { t/hectare }\end{array}$ \\
\hline $\begin{array}{c}\text { Not saline } \\
\text { (control) }\end{array}$ & 11 & 115 & 1265 & 56.2 \\
\hline Weak & 10 & 109 & 1080 & 47.9 \\
\hline Average & 7 & 97 & 679 & 30.1 \\
\hline
\end{tabular}

When cultivating tomato in the region, the selection of highly salt tolerant and high-yielding varieties and hybrids of tomato is of great importance (4 table). 
Table - 4

The effect of soil salinization on the productivity of various varieties and hybrids of tomato

\begin{tabular}{|c|c|c|c|c|c|c|}
\hline \multirow[b]{2}{*}{ № } & \multirow{2}{*}{$\begin{array}{c}\text { Varieties and hybrids of } \\
\text { tomato }\end{array}$} & \multicolumn{3}{|c|}{ Productivity. t/hectare } & \multicolumn{2}{|c|}{ yield reduction } \\
\hline & & non-saline & $\begin{array}{c}\text { slightly } \\
\text { saline }\end{array}$ & saline & t/ha & $\%$ \\
\hline 1. & Volgograd 5/95 & 51.1 & 45.2 & 32.0 & 19.1 & 37.3 \\
\hline 2. & TMK-22 & 36.0 & 32.7 & 23.9 & 12.1 & 33.6 \\
\hline 3. & Dark red 2027 & 47.5 & 41.6 & 31.1 & 16.4 & 34.5 \\
\hline 4. & Peremoha 165 & 44.2 & 37.5 & 27.5 & 16.7 & 37.7 \\
\hline 5. & East 36 & 53.2 & 46.8 & 33.8 & 19.4 & 36.4 \\
\hline 6. & Progressive & 42.4 & 36.9 & 23.3 & 19.1 & 45 \\
\hline 7. & Andijan & 51.9 & 39.5 & 25.0 & 26.9 & 51.8 \\
\hline 8. & October & 74.0 & 56.9 & 32.6 & 41.4 & 55.9 \\
\hline 9. & Otranto $\mathrm{F}_{1}$ & 44.8 & 38.0 & 20.6 & 24.6 & 54.9 \\
\hline 10. & Classic (Classik) $\mathrm{F}_{1}$ & 40.8 & 35.1 & 28.5 & 12.3 & 30.1 \\
\hline 11. & Shady Lady $\left(\mathrm{F}_{1}\right)$ & 51.9 & 43.7 & 23.3 & 28.6 & 55.1 \\
\hline 12. & Somma $F_{1}$ & 25.2 & 211 & 17.7 & 7.5 & 29.7 \\
\hline 13. & Incos $F_{1}$ & 62.0 & 49.9 & 30.6 & 31.4 & 50.6 \\
\hline 14. & AK-TOR $F_{1}$ & 53.2 & 47.1 & 27.4 & 25.8 & 48.4 \\
\hline 15. & Linde $F_{1}$ & 46.6 & 40.4 & 25.9 & 20.7 & 44.4 \\
\hline
\end{tabular}

As can be seen from the data given in Table 4, tomato salinity decreases during soil salinization. Domestic varieties proved to be more salt tolerant compared to hybrid plants. In saline soils in zoned varieties, the yield decreased by 33.6$51.8 \%$. Among hybrid varieties, they turned out to be unstable hybrids of Shady Lady $\left(\mathrm{F}_{1}\right)$, (decrease in yield 55.1\%), Otranto (Otranto) $\mathrm{F}_{1}$ (decrease in yield $54.9 \%$ ) and Inkos (Incos) $\mathrm{F}_{1}$ (decrease in yield $50.6 \%$ ).

\section{CONCLUSIONS}

The total area of irrigated lands of the Republic of Karakalpakstan is 511.40 thousand hectares (2019), of which 360.54 thousand hectares $(71 \%)$ are saline. In these conditions, agricultural crops require special agricultural practices. Field germination of tomato seeds was saline in soils 57 $69 \%$ (control plants $87 \%$ ), under highly saline soils there are no seedlings. Salinization of the soil affects the phenological phases of plant development. When salinization of the soil, the emergence of seedlings is delayed by 2-4 days, compared to control plants. flowering begins in lightly saline soils on day 53, on medium saline soils on day 54 , in control plants on day 50 from emergence. Fruit ripening begins in saline soils 10-14 days later, compared to control plants. Soil salinity negatively affects the formation of fruit elements. In saline soil, productivity decreases by 8.3-26.1 t/ha compared to control plants. In the cultivation of tomato in saline soils, the selection of highly salt tolerant varieties and hybrid races is important The total yield of domestic varieties for non-saline soils was 36.0-79.0 t/ha, for lightly saline soils 32.7-56.9 t/ha, and for mediumsaline soils 23.9-33.8 t/ha, hybrid varieties 25.2-51.9 t/ha, 21.1-49.9 t/ha, 17.7-28.5 t/ha, respectively.

\section{Recommendations to production}

1. On saline soils, carry out irrigation irrigation of lands: the norm of irrigation irrigation for lightly saline soils is $2000-3000 \mathrm{~m}^{3} / \mathrm{ha}$, for medium saline soils $3500-4000 \mathrm{~m}^{3} / \mathrm{ha}$, for highly saline soils $5000-6000 \mathrm{~m}^{3} / \mathrm{ha}$.

2. Widely use the most salt-tolerant and productive zoned varieties Volgogradsky 5/95, Dark Red 2027, Andijan, October and from hybrid varieties Inkos (Inkos) $\mathrm{F}_{1}, \mathrm{AK}-\mathrm{TOP} \mathrm{F}_{1}$, Shady Lady (Shady Lady) $\mathrm{F}_{1}$.

\section{REFERENCES}

1. Azimov B.Z., Azimov B.B. (2002), "Metodologiy for conducting an experiment in vegetable growing, melon growing and potato growing”. Tashkent, p. 170.

2. Azimov B.Z., Azimov B.B. (2006), "Static analysis experience results". Tashkent, p. 160.

3. Genkey T.A. (1954), Salt tolerance of plants and ways of its directed increase. - M.: Academy of Sciences of the USSR, p. 217.

4. Armor B.A. (1979), "Methods of field experience”. M. Kolos, p. 412. 
5. Zuev V.I. (1977), Features of cultivation of vegetable crops on saline soils. Tashkent: FAN, p. 166.

6. Ibragimov M.Yu. (1994), Pumpkin cultures of the lower reaches of the Amu Darya River (varietal diversity, morphobiology, growing technology). //Avtorev. diss. for a job. scientist step. Doct. from. - x. sciences. - Tashkent, p. 40.

7. Kalashnikov K. (1972), Salt tolerance of vegetable crops and potatoes //Potatoes and vegetables. №3. P. 17-19.

8. Kimberg N.V., Kuchebey M.I., Schuvalova S.A. (1964), Soils of the Karakalpak Autonomous Soviet Socialist Republic. In the book: Soils of the Uzbek SSR. Tashkent. T.Z. p. 5-132.

9. Kovalskaya E.M. (1958), Fiziol. Rast., 5,5.

10. Kovda V.A. (1947), The origin and regime of saline soils. - M.: Publishing House of the Academy of Sciences of the USSR, Tashkent, $p$. 375 .

11. Kovda V.A., Egorov V.V. and others. (1960), Classification of soils according to the degree and quality of salinity in connection with the salt tolerance of plants. //Bot. USSR Journal. Tashkent, 4. - №45. p. 1123-1131.

12. "Methods of field experience in vegetable growing and melon growing." Edited by V.F.Beliki, and G.L. Bondarenko M. 1979. p. 150.

13. Methods of agrochemical, agrophysical and microbiological studies in irrigated cotton areas Union of NII 1963.

14. Orlovsky N.V. (1951), Permissible, harmful and toxic salt concentrations in the soils of central Baraba. //Proceedings of the Novosibirsk Agricultural Institute. Issue. Viii. p. 95-103.

15. Bolurin M.C. Fernandez E.G., Cruz V., Cuartero J. (1991), Salinity tolerance of four wild tomato species using Vegetetive yeldsalinity response curves. //Amer. Soc. Hort. Sci. 166. №2. p. 286290.

16. Feligin A. (1990), Interactive affects of salinity and ammonium nitrate ratio on growth and chemical composition of melon plants. //Plant Nutr. -133. №10. p. 1257-1269. 